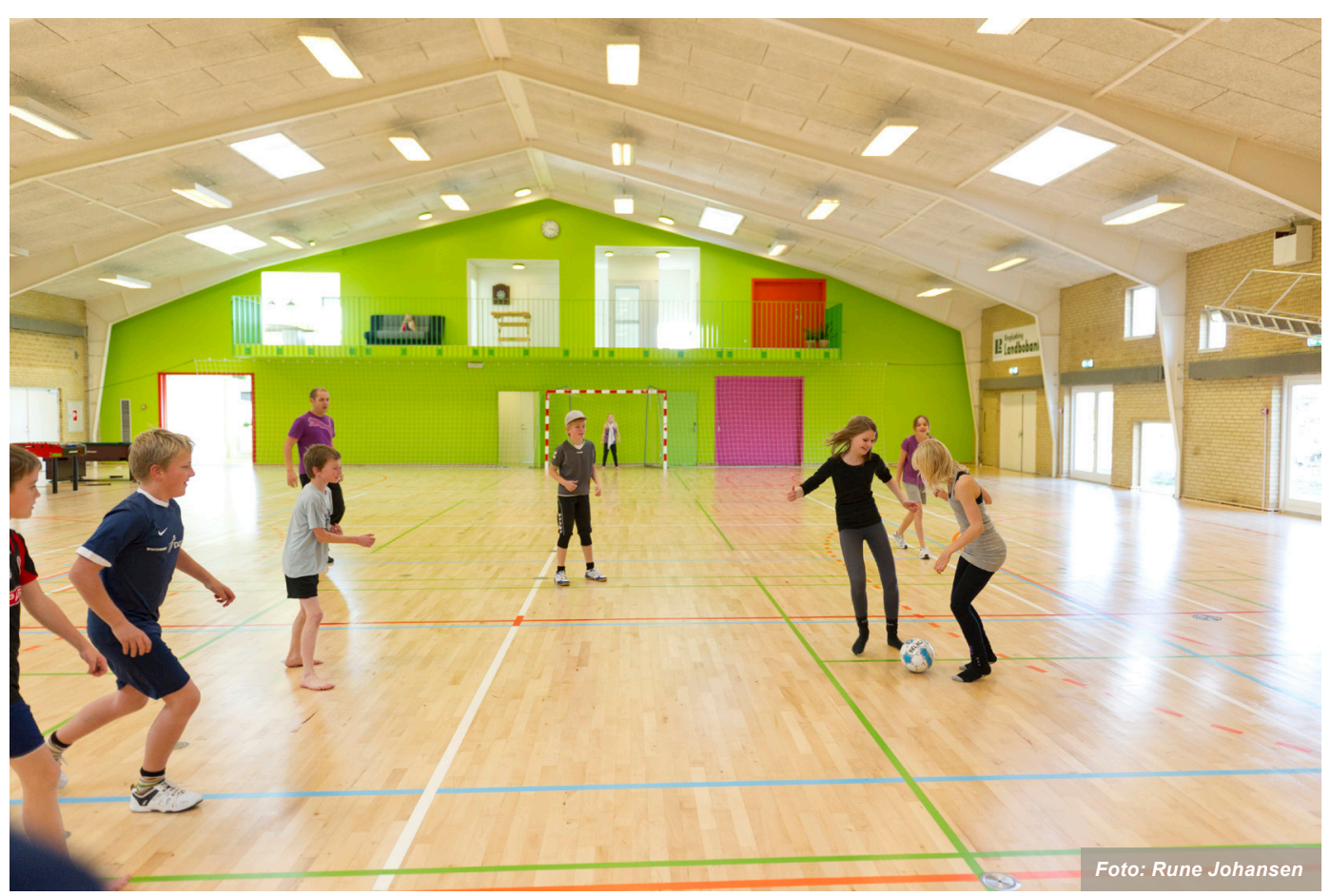

\title{
Skaber ledere af idrætsanlæg offentlig værdi?
}

\author{
PETER FORSBERG \& EVALD BUNDGÅRD IVERSEN
}

Denne artikel undersøger otte ledere af idrætsanlægs skabelse af offentlig værdi med baggrund i Ledelseskommissionens anbefaling om, at offentlige velfærdsinstitutioner skal sætte borgerne først og skabe værdi for hele lokalsamfundet. Artiklen anvender Moore's (1995) teori om offentlig værdiskabelse til at undersøge, hvordan lederne i anlæggene italesætter anlæggets vision om værdiskabelse, samt hvilke handlinger lederne tager for at nærme sig visionen. Artiklen viser, at lederne har intentioner om at skabe værdi for idrætsforeninger og borgere bredt set, men at lederne operationelt fokuserer på idrætsforeningerne. Intentionerne om også at have fokus på borgere bredt set, fortaber sig i de daglige driftsopgaver. 


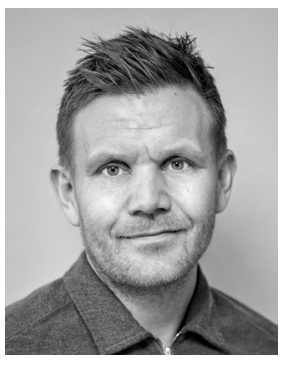

\section{PETER FORSBERG}

Ph.d.-stipendiat ved Idrættens Analyseinstitut og Center for forskning i

Idræt, Sundhed og Civilsamfund, SDU

peter.forsberg@idan.dk

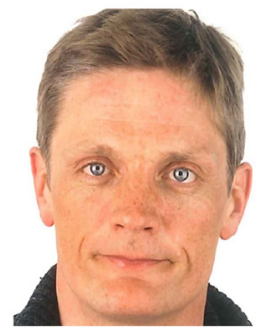

EVALD BUNDGÅRD IVERSEN

Lektor, ph.d.

Center for forskning i Idræt, Sundhed og Civilsamfund, SDU

eiversen@health.sdu.dk

\section{INDLEDNING}

Idrætsanlæg udgør langt den største udgift til breddeidrætten i Danmark (Kulturministeriet, 2014). Udgifterne til idrætsanlæg afholdes overvejende af kommunerne, og fra 2013-2017 brugte landets 98 kommuner i gennemsnit 4,5 mia. kr. om året på drift og etablering af idrætsanlæg (Danmarks Statistik, 2017). I det perspektiv er det bemærkelsesværdigt, at vi ved meget lidt om idrætsanlægs drift og ledelse, og at der først inden for de senere år er kommet fokus herpå (Forsberg \& Iversen, 2019; Forsberg, Iversen, \& Høyer-Kruse, 2017). I et historisk perspektiv har ledelsesspørgsmålet i idrætsanlæg haft begrænset interesse fra kommuners side (Ibsen, 2011), hvilket står i kontrast til opmærksomheden for ledelse i andre typer af decentrale velfærdsinstitutioner (Klausen, 2006; Klausen, Michelsen, \& Nielsen, 2011; Pors, 2005, 2010). Den begrænsede interesse for ledelse af idrætsanlæg har betydet, at ledelse af idrætsanlæg primært har handlet om de tekniske sider af idrætsanlægs drift (Forsberg \& Iversen, 2019), og at en stor del af lederne af landets idrætsanlæg ikke i samme grad som ledere i andre decentrale velfærdsinstitutioner (som f.eks. daginstitutioner, plejehjem og skoler) har en formel lederuddannelse (Forsberg, Iversen \& Høyer-Kruse, 2017).

Fra forskningsmæssig side er det vist, at ledelse har betydning for velfærdsinstitutioners præstation og kvaliteten af borgerrettede velfærdsydelser (Andersen, Andersen, \& Pallesen, 2016), og derfor har der fra politisk side også været stor 
opmærksomhed på ledelse af decentrale velfærdsinstitutioner mere generelt. Senest nedsatte regeringen Ledelseskommissionen, som skulle komme med anbefalinger til, hvordan ledelse kan øge den offentlige sektors præstation (Regeringen, 2017). Ledelseskommissionens (2018) hovedanbefaling går på, at offentlige ledere (og institutioner) skal sætte borgerne først. Det gør ledere ifølge kommissionen ved at sætte værdiskabelse for borgere og samfund i centrum i alle afkroge af den offentlige sektor. Uanset at der ikke har været meget fokus på ledelse af idrætsanlæg, argumenterer vi i denne artikel for, at ledelsens evne til at arbejde med offentlig værdiskabelse i idrætsanlæg er væsentlig at have for øje blandt andet med henvisning til Ledelseskommissionens anbefalinger. I artiklen forfølger vi derfor dette fokus på at skabe offentlig værdi ved at tage udgangspunkt i Moore’s (1995) ledelsesmodel for offentlig værdiskabelse. Ifølge Moore (1995) er offentlige institutioners overordnede formål at skabe offentlig værdi. Offentlig værdi er imidlertid et relativt begreb, og det varierer fra institution til institution, og fra fagområde til fagområde, hvordan ledere skaber offentlig værdi. I denne artikel undersøger vi på baggrund af interessen for offentlig værdiskabelse, i hvilken grad ledere af otte idrætsanlæg i tre danske kommuner inddrager overvejelser om offentlig værdi i deres ledelsesarbejde. Vores forskningsspørgsmål er:

1) Hvordan italesætter ledere idrætsanlægs vision for værdiskabelse?

2) Hvilke handlinger udfører ledere for at realisere visionen?

Artiklens relevans understreges af, at idrætsanlæg står over for en række udfordringer. Mange idrætsanlæg er presset økonomisk af kommunale besparelser (Iversen, 2018), og idrætsanlæg kunne bruges mere og have flere voksne brugere (Høyer-Kruse, Iversen, \& Forsberg, 2017). Disse udfordringer synes i nogen grad at kunne imødegås via fokus på offentlig værdiskabelse. Med baggrund i et offentligt værdiperspektiv giver vi derfor indblik i, hvordan ledere af idrætsanlæg søger at tackle og håndtere idrætsanlægs udfordringer, og artiklen kan inddrages i lederes og kommuners fremtidige bestræbelser på at forbedre idrætsanlægs præstation til gavn for borgere og lokalsamfund.

I næste afsnit giver vi et kort overblik over den hidtidige forskning i ledelse af velfærdsinstitutioner, og vi fokuserer på Moore's teori om offentlig værdi. Dernæst gennemgår vi casestudiemetoden, som anvendes i denne artikel, hvorefter vi først analyserer og dernæst diskuterer resultaterne af de otte casesanalyser. Til slut afrunder vi artiklen med at fremhæve de væsentligste konklusioner. 


\section{LITTERATUROVERBLIK OG TEORI}

Denne artikel trækker på Moore's (1995) teori om offentlig værdi. Inden vi introducerer teorien nærmere, er fokus indledningsvist kort på at placere teorien inden for forskningen i ledelse af idrætsanlæg og velfærdsinstitutioner.

Selvom idrætsanlæg i Danmark og mange andre europæiske lande overvejende er offentligt finansierede (Ibsen, Nichols, \& Østerlund, 2016), har der som nævnt indledningsvis været meget lidt fokus på idrætsanlægs drift og ledelse. Inden for det seneste årti er der dog kommet øget fokus på området. Iversen og Forsberg (2014) har vist, at der findes få mål for idrætsanlæg, og at idrætsanlægs præstation ikke måles systematisk. Iversen $(2015,2017)$ har med udgangspunkt i selvejende idrætsanlæg desuden vist, at kommunal incitamentsstyring kan øge idrætsanlægs benyttelse ved at øge lederes opmærksomhed på dette, men også at tiltag for at øge idrætsanlægs benyttelse (Iversen, 2018) har det svært, når der samtidig gennemføres besparelser. Senest har forskningsprojektet Fremtidens idrætsfaciliteter ${ }^{1}$ med baggrund i 290 idrætsanlæg fordelt i 23 kommuner vist, at idrætsanlæg er udfordrede i forhold til deres benyttelse, men har høj brugertilfredshed og god fysisk tilstand (Høyer-Kruse et al., 2017).

Det begrænsede fokus på ledelse af idrætsanlæg gør, at det er nødvendigt at tage afsæt i litteratur om ledelse af andre typer af institutioner, som deler træk med idrætsanlæg. Vi tager derfor afsæt i forskning i decentrale velfærdsinstitutioner, og hvordan ledere af disse har positiv indflydelse på skabelse af offentlig værdi. Ifølge Andersen et al. (2016) viser den hidtidige forskning, at 1) transformationsledelse, 2) transaktionsledelse og 3) ledelse som styring har positiv indflydelse på borgernes udbytte af offentlige ydelser og dermed skabelsen af offentlig værdi. Transformationsledelse handler om at lede med udgangspunkt i en vision (uddybes i næste afsnit), mens transaktionsledelse og ledelse som styring er delvist sammenfaldende og omhandler, hvordan formelle strukturer - blandt andet belønning og sanktioner - påvirker ledere og medarbejdere til at handle på særlige (hensigtsmæssige) måder. Eksempelvis viser Iversen (2015) med sit studie af selvejende idrætsanlæg, som nævnt ovenfor, at forandringer i økonomiske incitamenter kan øge aktivitetsniveauet i idrætsanlæg. De positive resultater i Iversens studie synes at ligge i forlængelse af Andersen et al. (2016), der dog også understreger, at eksistensen af uklare eller flertydige målsætninger, manglende vilje blandt ledere og medarbejdere, samt begrænset troværdig til politikere kan udviske effekterne af ledelse som styring og økonomiske incitamenter (se Andersen, Jakobsen, Serritzlew, \& Pallesen, 2010). Problematikken omkring uklare eller flertydige målsætninger er relevant i forhold til ledelse af idrætsanlæg, hvor der sjældent findes konkrete målsætninger for idrætsanlægs virke (Iversen \& Forsberg, 2014).

Den begrænsede fokusering på mål og målsætninger for idrætsanlæg gør trans-

1 https://idan.dk/idan-undersoeger/fremtidens-idraetsfaciliteter/ 
formationsledelse relevant. Kernen i transformationsledelse handler om lederes evne og opgave med at lede med baggrund i en vision (Andersen et al., 2016). Er visionen ikke givet udefra (f.eks. fra kommune eller politikere), er det op til lederne selv at skabe visionen. Visionen vil ofte have udgangspunkt $i$, hvad der skaber værdi for borgerne, og som vi uddyber senere, deler transformationsledelse en forestilling om ledere som visionsskabere med Moore's (1995) ledelsesmodel om offentlig værdi. Transformationsledelse handler således om at formulere og dele en vision, som har positiv indflydelse på kvaliteten af borgerrettede velfærdsydelser. Visionen rammesætter lederens handlinger, og i denne artikel ser vi på visionen i et offentligt værdiperspektiv, da vi bruger Moore's ledelsesmodel om offentlig værdi som en måde at bringe transformationsledelse i spil i idrætsanlæg.

\subsection{Idrætsanlæg og offentlig værdi}

Udgangspunktet for Moore (1995) er, at offentlige velfærdsinstitutioner sikrer overlevelse ved at skabe offentlig værdi. Politikere belønner offentlige velfærdsinstitutioner for skabelse af offentlig værdi ved at tildele dem økonomiske ressourcer. For at sikre deres overlevelse på sigt skal velfærdsinstitutioner derfor fremstå legitime, hvilket de blandt andet gør ved at dokumentere, hvordan de skaber offentlig værdi for borgere og samfund (Moore, 2013). Modellen sammenfatter Moore i en strategisk trekant, som er vist i en tilpasset udgave i figur 1 . Trekanten definerer de centrale dele af ledelsesopgaven i idrætsanlæg i forhold til at skabe offentlig værdi.

Figur 1: Den strategiske trekant

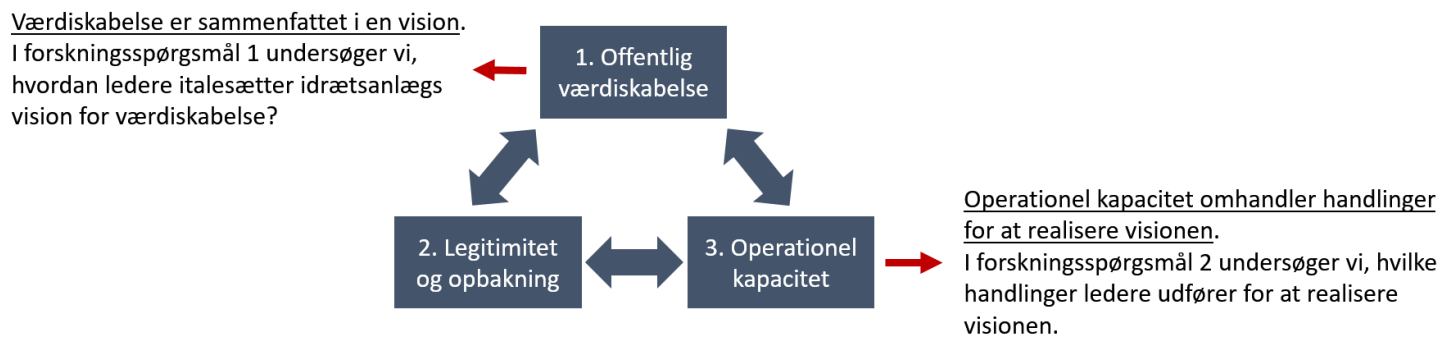

Efter Moore 2000; figur 2, s. 198

Omdrejningspunktet for ledelse af velfærdsinstitutioner er i Moore's optik skabelse af offentlig værdi, som er trekantens første hjørne. Forestillinger om, hvordan idrætsanlægget skaber offentlig værdi for borgere og lokalsamfund, er ideelt set sammenfattet i en vision, som danner udgangspunkt for leder og medarbejdere. Det første hjørne danner baggrund for vores første forskningsspørgsmål, hvor vi 
undersøger, hvordan ledere italesætter idrætsanlægs vision for værdiskabelse. Trekantens andet hjørne består af legitimitet og opbakning. Her er fokus på, hvordan lederen dokumenterer skabelse af offentlig værdi og hensigtsmæssigt forbrug af ressourcer over for bidragsydere (f.eks. politikere) for at sikre legitimitet. Vi fokuserer af pladshensyn ikke på dette hjørne i analysen, men berører det kort i artiklens konklusion. Trekantens tredje hjørne er operationel kapacitet, som handler om, hvordan lederen omsætter tildelte ressourcer til offentlig værdi for borgere og lokalsamfund. Dette hjørne danner baggrund for vores andet forskningsspørgsmål, hvor vi undersøger, hvilke handlinger lederne udfører for at nærme sig visionens realisering. Pointen med den strategiske trekant er, at lederen skal skabe fit mellem de tre hjørner således, at operationelle handlinger løbende justeres og tilpasses vision og ressourcer. Ændres vision eller tilgængelige ressourcer, skal lederen tilpasse de operationelle handlinger (og vice versa) (illustreret ved pile i figur 1). I denne artikel har vi særligt fokus på forholdet mellem vision og operationelle handlinger, da vi med udgangspunkt i visionen undersøger, om og evt. hvilke handlinger ledere initierer for at realisere visionen.

\subsection{Operationalisering af offentlig værdi}

Moores teori om offentlig værdi er blevet kritiseret for ikke at definere offentlig værdi præcist, hvilket gør, at offentlig værdi kan være "all things to all people" (Rhodes \& Wanna, 2007, s. 408, 2008). Vi er dog her på linje med de dele af litteraturen, der argumenterer for, at der delvist er tale om en misforståelse (Alford \& Flynn, 2009), idet et centralt element i Moore's (1995) tilgang er, at ledere skal agere som "explorers" og søge efter, hvordan de kan skabe offentlig værdi (s. 299300). Med baggrund i en dansk kontekst har Greve (2009) argumenteret for, at Moore's tilgang må betegnes som en aktiv ledelsesform. Greve's pointe er, at ledere ikke kan læne sig tilbage og vente på, at politikere leverer en færdig vision og handleplan for, hvordan institutioner skal skabe offentlig værdi, men i stedet aktivt må søge efter, hvordan de skaber offentlig værdi. Den pointe passer godt til idrætsanlæg, hvor der kun findes få og overordnede forventninger om anlægs skabelse af offentlig værdi (Iversen \& Forsberg, 2014).

I artiklen interesserer vi os derfor for, hvordan ledere definerer offentlig værdi. Vores udgangspunkt er med henvisning til Moore (1995), at offentlig værdi bestemmes af politikere og befolkning og er nedfældet i politiske dokumenter. Vi tager derfor afsæt i de politiske ambitioner om offentlig værdi, som vi finder i tre kommuners idrætspolitikker, virksomhedsplaner, samarbejdsaftaler og partnerskabsaftaler mellem anlæg og kommune (vi anvender facilitetspolitik som en samlet betegnelse herfor). Facilitetspolitikkerne fungerer således som en overordnet ramme for de otte anlægs formål, som skabelsen af offentlig værdi sker med baggrund i. 


\section{CASESTUDIEMETODE}

Vi anvender casestudiemetode til at undersøge de to forskningsspørgsmål, idet vi undersøger et nutidigt fænomen i dets virkelige kontekst (Yin, 2014). Vi har brugt forskellige kilder til at forstå de enkelte cases detaljerigdom og kontekst, men vi trækker i denne artikel primært på interviews med lederne af idrætsanlæggene. Vi inddrager dog også interviews med ledernes øvre leder (bestyrelsesformanden i selvejende anlæg, idrætschef i kommunale anlæg) og forvaltningschefer samt skriftlige dokumenter, som angiver facilitetspolitikken (se tabel 1). Brugen af flere kilder gør det muligt at skille fænomen fra kontekst (Michelsen la Cour, 2013; Yin, 2014), og vi sigter i artiklen på at forstå ledernes handlinger ud fra den pågældende kontekst. Vi søger at få forståelse for, hvad der er generelle ledelseshandlinger, og hvad der skyldes det pågældende idrætsanlægs kontekst. Vi undersøger casene enkeltvis (within-case analyse) og foretager en cross-case-analyse, hvor vi søger generelle slutninger, som er de handlinger, som træder frem på tværs af cases (Stake 2005; Miles \& Hubermann, 1994).

\subsection{Generalisering, caseudvælgelse og analysestrategi}

Flyvbjerg (2006) argumenterer for, at det er muligt at generalisere på baggrund af særligt velvalgte cases, mens Gerring (2004) argumenterer for, at det er muligt at generalisere til lignende cases. Hovedformålet med dette studier er at undersøge otte idrætsanlægs skabelse af offentlig værdi, og vi har et ønske om at bidrage til viden, som kan appliceres bredere end til de otte idrætsanlæg, som er udvalgt til nærværende undersøgelse. Derfor er caseudvælgelsen central, som er foretaget med udgangspunkt i to forhold. For det første har vi udgangspunkt i Gerrings (2004) argument om udvælgelse af cases med ensartede baggrundsforhold. Det øger ifølge Gerring casestudiets forklaringskraft. Når baggrundsforhold er relativt ens, øges sandsynligheden for, at centrale ledelseshandlinger for den specifikke type af anlæg kommer til syne. Det forbedrer muligheden for at generalisere fund til anlæg med lignende karakteristika. For det andet har vi udgangspunkt i Flyvbjergs (2006) argument om den kritiske case. Logikken i den kritiske case er, at finder vi det ikke i denne case, er det usandsynligt, at vi finder det i andre cases. Vi har valgt anlæg med høj tilfredshed/benyttelse ud fra en forventning om, at lederne i disse anlæg lykkes, fordi de har en særlig opmærksomhed rettet mod at sikre høj benyttelse og brugertilfredshed. Mere præcist har vi haft følgende overvejelser i forbindelse med udvælgelsen:

- Anlæggenes størrelse: Institutioners størrelse betragtes i ledelseslitteraturen som et afgørende forhold for ledelse (Bro, 2016; Klausen, 2006). Vi har derfor søgt at udvælge anlæg på omtrent samme størrelse. Det har vi gjort med baggrund i data fra facilitetsdatabasen.dk, som indeholder information 
om alle idrætsanlæg i Danmark. Ifølge databasen er de mest almindelige faciliteter i idrætsanlæg den almindelige idrætshal og udendørs fodboldbaner, som findes i henholdsvis 1.288 og 1.064 anlæg. Færre anlæg (379) har en svømmehal. I alle otte anlæg er der adgang til idrætshal og udendørs fodboldbane, mens fem ud af otte anlæg også har en svømmehal/-bassin.

- Den ledelsesmæssige situation: På linje med Iversen (2015), og i forlængelse af Bozeman (1984), argumenterer vi for, at der i forhold til vores fokus er flere ligheder end forskelle mellem kommunale og selvejende anlæg. Begge typer af anlæg er almennyttige og er vævet tæt ind i kommunernes økonomi og administration. Med den antagelse in mente har vi udvalgt såvel selvejende som kommunale anlæg, idet vi antager, at den konkrete ledelsesmæssige situation betyder mere end det formelle organisatoriske setup. Vi har derfor udvalgt anlæg, hvor den daglige leder af anlægget står til ansvar for en øvre ledelse højere oppe i hierarkiet.

- Høj tilfredshed og benyttelse: Vi har søgt at vælge anlæg, som kendetegnes ved høj benyttelse og brugertilfredshed. Anlæggene kendetegnes således ved god præstation på tilfredshed og benyttelse, og vi har en antagelse om, at dette kunne skyldes en bevidsthed fra ledelsen om, at disse indikatorer bidrager til at skabe offentlig værdi. Dermed antager vi, at de ledelseshandlinger, som er knyttet til disse indikatorer, vil være mere synlige i anlæg med god præstation på brugertilfredshed og benyttelse end i anlæg med lav eller middelmådig præstation. Finder vi ikke indikatorer på en sådan kobling i disse anlæg, er det mindre sandsynligt, at sådanne koblinger findes i anlæg med lavere niveauer af brugertilfredshed og kapacitetsbenyttelse.

De otte cases udtrykker således relativt ensartede idrætsanlæg, som kendetegnes ved høj benyttelse og brugertilfredshed. Med baggrund i argumentet om den kritiske case, forventer vi, at vi ved at studere lederne i disse anlæg får indsigt i, hvorvidt og evt. hvordan ledere af idrætsanlæg skaber offentlig værdi i denne type af anlæg, der jf. ovenstående er meget udbredte i Danmark.

\subsection{Dataindsamling}

Tabel 1 nedenfor viser en oversigt over den indsamlede data og dens indhold. Vi har sløret specifikke data om anlæggene for at sikre kommuner, anlæg og lederes anonymitet. Det betyder også, at vi i analyserne kun i begrænset omfang anvender citater. Casestudierne trækker især på interviews med lederne, som er blevet interviewet en eller to gange af ca. en times varighed per gang i løbet af 2017/2018. Der er anvendt en semistruktureret interviewguide, som er blevet udarbejdet med baggrund i Moore's teori og har haft særligt sigte på at spørge ind til den strategiske trekants første og tredje hjørne. Der er også blevet gennemført interviews med de 
otte lederes øvre leder samt forvaltningscheferne i de tre kommuner. Det er gjort for at få indblik i konteksten og forventningerne til ledere/anlæg. Endelig er facilitetspolitikker blevet analyseret for at forstå konteksten for de enkelte anlæg. Det har været væsentlig i forhold til forberedelse af spørgeguides til interviews samt analyser. Dokumentanalyserne har også været anvendt til at få indblik i de politiske forventninger til idrætsanlæggene og deres overordnede formål. Alle interviews er blevet transskriberet og data (inklusiv dokumenter) er blevet analyseret med NVivo.

Tabel 1: Oversigt over dataindsamling og indhold

\begin{tabular}{|c|c|c|}
\hline Datatype & Empiri & Indhold \\
\hline \multirow[t]{3}{*}{ Interviews } & $\begin{array}{l}\text { Interviews med ledere i de otte } \\
\text { anlæg }\end{array}$ & $\begin{array}{l}\text { - Semistruktureret interview } \\
\text { - Spørgeguide fokuserer på den strategiske trekants } \\
\text { første og tredje hjørne - herunder rammerne for } \\
\text { visionsarbejdet, ledernes italesættelse af anlæggets } \\
\text { vision samt handlinger for at optimere benyttelse og } \\
\text { tilfredshed. }\end{array}$ \\
\hline & $\begin{array}{l}\text { Interviews med de otte anlægsle- } \\
\text { deres øvre ledere (dvs. formænd } \\
\text { i selvejende anlæg, idrætschef i } \\
\text { kommunale anlæg) }\end{array}$ & $\begin{array}{l}\text { - Semistruktureret interview } \\
\text { - Spørgeguide fokuserer på rammerne for visi- } \\
\text { onsarbejdet, forventninger til ledere i forhold til } \\
\text { visionsarbejdet og optimering af benyttelse og } \\
\text { tilfredshed. }\end{array}$ \\
\hline & $\begin{array}{l}\text { Interviews med de tre forvaltnings- } \\
\text { chefer i kommunerne }\end{array}$ & $\begin{array}{l}\text { - Semistruktureret interview } \\
\text { - Spørgeguide fokuserer på at få blik for den overord- } \\
\text { nede kontekst anlægslederne agerer i. Herunder } \\
\text { forventninger til idrætsanlæg og idrætsanlæggenes } \\
\text { rolle/betydning for idrætten i kommunen. }\end{array}$ \\
\hline $\begin{array}{l}\text { Dokument- } \\
\text { analyse }\end{array}$ & $\begin{array}{l}\text { Analyse af de tre kommuners } \\
\text { facilitetspolitik (idrætspolitikker, virk- } \\
\text { somhedsplaner, samarbejdsaftaler } \\
\text { og partnerskabsaftaler) }\end{array}$ & $\begin{array}{l}\text { - Indblik i den overordnede kontekst anlægslederne } \\
\text { agerer i. Herunder forventninger til idrætsanlæg } \\
\text { og idrætsanlæggenes rolle/betydning for idrætten i } \\
\text { kommunen. }\end{array}$ \\
\hline
\end{tabular}

\section{ANALYSE}

Analysen er delt i fire afsnit. Første del undersøger de overordnede rammer for visionsarbejdet, mens anden del undersøger ledernes italesættelse af idrætsanlæggets vision. Dernæst følger to afsnit, som ser på ledernes handlinger for at nærme sig visionens realisering. Det første afsnit fokuserer på anlæggenes benyttelse, hvorefter det andet afsnit ser på brugernes tilfredshed. 


\subsection{Rammerne for visionsarbejdet}

Idrætsanlæggenes overordnede formål tjener som en baggrund for ledernes skabelse af offentlig værdi. Beskrivelse af anlæggenes formål finder vi i de tre kommuners facilitetspolitikker. I en kommune italesættes idrætsfaciliteterne i kommunen som en "fælles ressource", der skal gøres tilgængelige for alle borgere, de foreningsbaserede såvel som de selvorganiserede og individuelle udøvere (Facilitetspolitik, kommune 1). I en anden kommune er det et mål for idrætsanlæggene, at "støtte idrætsforeninger og selvorganiserede borgeres" arbejde med at skabe velfungerende idrætsmiljøer. Kommunen prioriterer børn, unge og foreninger højt i idrætsanlæggene, men anlæggene skal også arbejde "målrettet” med at åbne anlæg for en bredere skare af borgere end foreningsmedlemmer (Facilitetspolitik, kommune 2). I en tredje kommune er det et formål for anlæggene, at sikre kommunens borgeres "naturlige gang" i anlæggene og medvirke til at fremme enhver form for idræt og sundhedsfremmende livsstil (Facilitetspolitik, kommune 3). Facilitetspolitikkerne i de tre kommuner nævner alle idrætsforeninger som en særlig målgruppe, men alle politikkerne angiver også, at idrætsanlæggene skal være ramme om alle borgere i lokalsamfundet. Idrætsanlæggenes overordnede formål er således knyttet til foreningsmedlemmer såvel som alle borgeres brug af idrætsanlæggene. Da formålene for alle anlæggene knytter an til idrætsforeninger og lokalsamfundet, undersøger vi, hvordan forestillingerne om skabelse af offentlig værdi er knyttet hertil. I teksten anvender vi kursiv til at henvise til de to målgrupper: idrætsforeninger udtrykker et fokus primært på idrætsforeninger, mens lokalsamfundet udtrykker et bredere fokus på både idrætsforeninger og lokalsamfundet. En (optimal) efterlevelse af facilitetspolitikkernes ambition om skabelse af offentlig værdi forudsætter, at både idrætsforeninger og lokalsamfundet prioriteres (dvs. det vi referer til som lokalsamfundet).

Ud over anlæggenes overordnede formål, er det også relevant at se på, om der kan identificeres en vision for det konkrete anlæg på skrift, og om lederne har et ansvar for at realisere visionerne. Som det fremgår af tabel 2, er det bortset fra i anlæg 6 den øvre leder, som har ansvaret for visionsarbejdet. Det er kun i anlæg 6, at ansvaret ligger hos lederen af idrætsanlægget. I alle anlæg fortæller lederne, at de (i forskelligt omfang) har været med til at formulere visionen og er blevet taget med på råd. Men det endelige ansvar (bort set fra anlæg 6) ligger hos den øvre ledelse. Uanset at lederne af idrætsanlægget ikke har ansvaret for visionsarbejdet, er det (jf. transformationsledelse og Moore's teori) væsentligt, at lederne har kendskab til visionerne, da de skulle kunne kommunikere og indfri ambitionerne. 
Tabel 2: Rammerne for visionsarbejdet i de otte anlæg

\begin{tabular}{|c|c|c|}
\hline Anlæg & Hvem har ansvar for visionsarbejdet? & Findes visionen på skrift? \\
\hline Anlæg 1 & To underudvalg i bestyrelsen & $\begin{array}{l}\text { Ja - i en virksomhedsplan (levn fra gammel } \\
\text { formand) }\end{array}$ \\
\hline Anlæg 2 & Bestyrelsen & Ja - i en virksomhedsplan \\
\hline Anlæg 3 & Bestyrelsen & $\begin{array}{l}\text { Ja - i en partnerskabsaftale med kommunen } \\
\text { (alle selvejende anlæg i kommunen skal have } \\
\text { en) }\end{array}$ \\
\hline Anlæg 4 & Bestyrelsen & $\begin{array}{l}\text { Nej - men lederen af idrætsanlægget har en } \\
\text { resultatkontrakt med bonus, når mål indfries }\end{array}$ \\
\hline Anlæg 5 & $\begin{array}{l}\text { Bestyrelsen (afhænger af arbejdet i } \\
\text { borgerforeningen) }\end{array}$ & Nej - men indgår i referater \\
\hline Anlæg 6 & Lederen af idrætsanlægget & $\mathrm{Nej}$ \\
\hline Anlæg 7 & Idrætschefen & $\begin{array}{l}\text { Ja - i en virksomhedsplan, som gælder for alle } \\
\text { anlæg i kommunen }\end{array}$ \\
\hline Anlæg 8 & Idrætschefen & $\begin{array}{l}\text { Ja - i en virksomhedsplan, som gælder alle } \\
\text { anlæg i kommunen }\end{array}$ \\
\hline
\end{tabular}

Der findes skriftligt materiale om visionen i fem anlæg (1, 2, 3, 7 og 8). I anlæg 1, 2 og 3 indgår visionerne i planer for de enkelte anlæg, som er et kommunalt krav. I anlæg 1 er visionen udarbejdet af en tidligere formand og er sat på standby, mens man i anlæg 2 er ved at igangsætte en ny visionsproces. I anlæg 7 og 8 er der tale om en vision for anlæggene i kommunen samlet set, som indgår i kommunens plan for alle kommunens idrætsanlæg, og der findes derfor ikke en specifik vision for anlæg 7 og 8. I resten af anlæggene er visionerne mundtligt formulereret.

\subsection{Ledernes italesættelse af vision}

Tabel 3 herunder viser visionerne, som de formuleres af lederne af idrætsanlæggene. Alle visionerne kan læses ind i et offentligt værdiskabelsesperspektiv, om end der er forskel på, hvem der søges at skabe offentlig værdi for. Visionerne kan således rangeres ud fra fokus på henholdsvis idrætsforeninger og lokalsamfundet (se tabel 4). I anlæg 1, 3, 4, 5 og 6 er fokus i visionen på at skabe offentlig værdi for lokalsamfundet. I anlæg 1 er fokus eksempelvis på at bidrage til det gode liv på landet, mens fokus i anlæg 6 er på at være en motor, der kan være med til at "holde gang i lokalsamfundet" (interview med leder). I anlæg 2, 7 og 8 er fokus på idrætsforeninger. I anlæg 2 er fokus eksempelvis på at udvikle anlægget efter foreningernes ønsker samt at lette det administrative arbejde for de frivillige ledere. I anlæg 7 er foreningernes tilfredshed omdrejningspunktet for anlæggets vision. 
Tabel 3: Ledernes italesættelse af visionen for anlægget

\begin{tabular}{|c|c|c|}
\hline Anlæg & Vision & $\begin{array}{l}\text { Handlinger for at realisere } \\
\text { visionen }\end{array}$ \\
\hline Anlæg 1 & $\begin{array}{l}\text { Mere end en hal og det gode liv på landet } \\
\text { Alle skal involveres }\end{array}$ & $\begin{array}{l}\text { Flere arrangementer } \\
\varnothing \text { ge/fastholde benyttelse }\end{array}$ \\
\hline Anlæg 2 & $\begin{array}{l}\text { Understøtte foreningernes virke ved at udvikle } \\
\text { idrætsanlægget } \\
\text { Gøre det lettere at være frivillig leder }\end{array}$ & $\begin{array}{l}\text { Udvidelse af anlægget (nyt udendørs } \\
\text { bevægelsesareal) } \\
\text { Administrativ støtte til foreninger }\end{array}$ \\
\hline Anlæg 3 & $\begin{array}{l}\text { Anlægget skal stå til rådighed for lokalsam- } \\
\text { fundet - henviser til folkeoplysningsloven (ikke } \\
\text { bestyrelsen) }\end{array}$ & $\begin{array}{l}\text { Samarbejdsaftaler giver nogle overordnede } \\
\text { linjer for anlægget }\end{array}$ \\
\hline Anlæg 4 & $\begin{array}{l}\text { Det naturlige samlingssted i byen - for folk der } \\
\text { dyrker idræt og folk, der ikke dyrker idræt }\end{array}$ & $\begin{array}{l}\text { Resultatkontrakt med mål og bonus } \\
\text { Højere benyttelse (knytte flere brugere til } \\
\text { anlægget) }\end{array}$ \\
\hline Anlæg 5 & $\begin{array}{l}\text { Bookes så meget så muligt } \\
\text { Tilbygning med indendørs halvgulv }\end{array}$ & $\varnothing$ ge benyttelse og antallet af arrangementer \\
\hline Anlæg 6 & $\begin{array}{l}\text { Byens sted - et samlingssted for børn, unge } \\
\text { og voksne, som indeholder idræt og andre } \\
\text { aktiviteter } \\
\text { Anlægget skal være en motor, som holder gang i } \\
\text { lokalsamfundet }\end{array}$ & $\begin{array}{l}\text { At udvikle noget } \\
\text { Aktiviteter målrettet børnefamilier }\end{array}$ \\
\hline Anlæg 7 & $\begin{array}{l}\text { At gøre de daglige brugere tilfredse } \\
\text { Vi går nye veje }\end{array}$ & Tilfredse brugere (dvs. foreninger) \\
\hline Anlæg 8 & $\begin{array}{l}\text { Inde: ramme om foreningsaktiviteter } \\
\text { Svøm: aktiviteter i svømmehallen for alle }\end{array}$ & $\begin{array}{l}\text { Tilfredse brugere (dvs. foreninger) } \\
\varnothing \text { ge svømmehallens benyttelse }\end{array}$ \\
\hline
\end{tabular}

Uanset ledernes fokus på henholdsvis idrætsforeninger og lokalsamfundet (se evt. tabel 4) går benyttelse og tilfredshed på tværs af de otte anlæg som centrale dimensioner, der er knyttet til skabelse af offentlig værdi. Derfor ser vi i det følgende på, hvordan lederne arbejder med at øge benyttelse og tilfredshed, og hvem de fokuserer på.

\subsection{Ledelsesinitiativer for at optimere benyttelse}

Når det gælder ledernes fokus i bestræbelserne på at optimere benyttelse, er fokus i særlig grad på idrætsforeninger (se evt. tabel 4). Det gælder også i de fem anlæg (1, $3,4,5$ og 6), hvor fokus i visionen ellers er på lokalsamfundet. Selvom anlæggenes visioner nævner offentlig værdi for foreninger og borgere uden for foreningslivet, så er fokus overvejende på idrætsforeninger, når der skal fordeles tider, og benyttelse skal optimeres. De tre anlæg (2, 7 og 8), som havde en vision med fokus overvejende på idrætsforeninger, fastholder dette fokus, når det kommer til benyttelse.

Dykker man nærmere ned i handlingerne for at optimere benyttelse, er det værd 
at bemærke, at der i ingen af de otte anlæg foretages systematiske målinger af benyttelse, og at der ikke eksisterer nogle mål for benyttelse. I anlæg 4 og 5 skal et vist bookingniveau (antal bookede timer) nås for at udløse det maksimale kommunale tilskud, og lederne i disse anlæg er meget opmærksomme på at opnå dette bookingniveau. Som en leder forklarer: "Altså min hovedopgave er, at vi rammer de timer, som vi kan få tilskud til fra kommunen (...) gør vi ikke det, kan der hurtigt mangle indtægter" (interview med leder). Lederne er knapt så optagede af, om bookingniveauet realiseres til benyttelse. Det bakkes op af en formand, som fortæller, at "når nogen har lejet hallen, så er det deres hal [uanset om de kommer], og så kan vi ikke leje den ud igen" (vores indsætning) (interview med formand).

På tværs af anlæggene tegner der sig fire overordnede strategier, som lederne anvender i bestræbelserne på at øge anlæggets benyttelse. De tre første har fokus på idrætsforeninger, mens den fjerde har fokus på lokalsamfundet. Den første strategi har baggrund i folkeoplysningsloven og den årlige fordeling af tider. Folkeoplysningsloven forpligter kommuner til at stille ledige kommunale lokaler til rådighed for idrætsforeninger samt yde tilskud til idrætsforeningers brug af egne eller lejede lokaler (folkeoplysningsloven). Fordelingsmøderne har afsæt i loven, og lederne (den øvre leder i anlæg 7 og 8) indkalder foreningerne til et møde, hvor tider fordeles mellem foreningerne. En leder fortæller, at foreningerne bevidst sættes sammen, så de kan få forståelse for hinandens ønsker og behov. Lederen har også bedt foreningerne forud for mødet om at komme med ønsker til tider. Så ved lederen, hvor der kan opstå konflikter, og lederen har inden mødet taget kontakt til efterskolen og "...snakkede med efterskolen, om de kan hjælpe med nogle haltider" (interview med leder). Forberedelsen giver lederen mulighed for at komme med løsningsforslag på mødet i de tilfælde, at der er sammenfald mellem foreningers ønsker.

Den anden strategi er baseret på dialog med foreningerne. Dialogen foregår løbende og sker både tilfældigt, når leder og foreningsformænd støder ind i hinanden i hverdagen, eller mere bevidst på ledernes initiativ. Et eksempel på det sidste er en leder, som holder sig opdateret og følger med i foreningernes trivsel: "...de fleste foreninger har en facebookgruppe, og der ser man jo meget. F.eks. hvis de søger en træner. Så kan man jo lige skrive til dem og høre, om man kan hjæl$p e$ " (interview med leder). Lederne er meget bevidste om betydning af den daglige kommunikation, og de sætter også tid af til at opsøge den mere uformelle dialog. Lederen i anlæg 1 deltager eksempelvis i generalforsamlinger i foreninger for at være opdateret på deres trivsel, og lederen har i kortere perioder påtaget sig en rolle som kasserer i en forening for at holde den kørende. Lederen i anlæg 5 bruger ca. en halv time om dagen på smalltalk og kommer fra tid til anden til kampe og turneringer for at tale med foreningerne og vise interesse for deres aktiviteter. Det store fokus på foreningernes trivsel synes at hænge sammen med, at lederne 
gerne vil opretholde aktivitetsniveauet i foreningerne. Falder aktivitetsniveauet i foreningerne, er det frygten, at det på sigt vil få betydning for størrelsen af de kommunale tilskud til anlæggene.

Den tredje strategi går på at få nye aktiviteter etableret i foreninger. F.eks. ved at sælge haltider billigt $i$ en periode til nye foreninger eller aktiviteter. Eller ved at tage initiativ til nye aktiviteter, som senere kan organiseres i en forening. Lederen i et anlæg har ønsker om at skabe familieaktiviteter, men er tilbageholdende for at skabe dem selv og ser hellere, at de bliver organiseret i en forening. En lignende tankegang er til stede i anlæg 1, 4 og 5. Udgangspunktet i foreningerne er knyttet til folkeoplysningsloven og en oplevelse blandt lederne af, at foreningerne misbilliger, hvis lederen sætter aktiviteter i gang, som konkurrerer med foreningernes tilbud eller kan tage haltider fra dem. Et andet aspekt går på, at aktiviteter, som ikke er organiseret i foreninger i selvejende anlæg, ikke făr et kommunalt tilskud og derfor er dyre for borgere uden for foreningerne. En leder fortæller, at det var et problem, at en gruppe unge spillede basket uden for foreningsregi, idet "...det var jo for dyrt, for de skulle jo være en forening [for at vi kan fä tilskud til aktiviteten]. Så fikjeg dem til at kontakte håndboldforeningen, men så løb det ud i sandet" (vores indsætning) (interview med leder). Anlæggene kommer på den måde først og fremmest til at være for foreninger, hvilket dels hænger sammen med, at lederne gerne ser, at varige initiativer organiseres i foreninger, dels at det økonomisk er svært at skabe aktiviteter, som ikke har rod i foreninger, og som dermed er tilskudsberettigede.

Den fjerde strategi går på særlige arrangementer som eksempelvis foredrag, koncerter, bagagerumsmarked, banko eller fodbold på storskærm. Her er fokus rettet mod lokalsamfundet. Valget af de særlige arrangementer hænger blandt andet sammen med et ønske om at markedsføre sig, og en leder fortæller, at arrangementer er en del af en strategi om at øge lokalbeboernes kendskab til anlægget. De særlige arrangementer har dog den ulempe, at de skal passes ind i foreningernes faste træningsprogram, og det kan ifølge en leder give nogle problemer: "...hvis jeg tager en koncert eller et bankmøde ind, så aflyser jeg jo en fast træningsaften (...) Det kan jo godt give noget karambolage fra den berørte forening" (interview med leder). Lederne er derfor opmærksomme på og tilbageholdende for at aflyse for mange af foreningernes faste træningstider. Mens de særlige arrangementer kan skabe indtægter i selvejende anlæg, er en begrænsning i de kommunale anlæg, at de skaber udgifter i form af rengøring og ekstra forbrug af el og vand. De faste kommunale tilskud reguleres ikke, og der findes i disse anlæg ikke et økonomisk incitament for arrangementer. 


\subsection{Ledelsesinitiativer for at optimere tilfredshed}

Lederne er meget opmærksomme på, om de vante brugere er tilfredse med anlægget, og lederne sigter først og fremmest på at skabe offentlig værdi for idrætsforeninger (se evt. tabel 4). Alle ledere giver udtryk for, at det er afgørende for deres arbejde, at foreningerne er tilfredse. I et anlæg forklarer lederen, at "hvis foreningerne har det godt, så har vi det også godt” (interview med leder).

Med tanke på den centrale rolle som tilfredsheden hos idrætsforeninger har for ledernes arbejde, er det interessant at se på, hvordan lederne søger at skabe tilfredshed. Der er en stærk tro blandt lederne på, at foreningerne er tilfredse. Lederne fortæller, at hvis de ikke var tilfredse, ville de jo ikke være her, og lederne ser ingen grund til at måle eller spørge foreningerne systematisk til deres tilfredshed. En leder fortæller, at "når de ikke siger noget, så regner vi med, at det er $i$ orden" (interview med leder), mens en anden forklarer, at "hvis en forening er tavs om deres banetider og materialet, så er det jo faktisk et succeskriterie. Det tog mig et par år at vænne mig til, at der ikke kom en masse tilbage" (interview med leder). Det klare billede er, at fraværet af klager er et tegn for lederne på, at foreningerne er tilfredse. Det gælder på tværs af alle anlæggene. Lederen i anlæg 7 problematiserer denne tilgang. Lederen fortæller, at "man nok burde måle på tilfredshed", men forklarer også, at det er svært at måle tilfredshed, og at der ikke er tradition for måling i idrætsanlæg.

Lederne har dog handlinger i forhold til at skabe tilfredshed. Den centrale strategi er baseret på den løbende dialog med foreningerne. Lederne fortæller, at vi jo taler sammen i hverdagen, da vi jo er tæt på hinanden, og lederne trækker især på den daglige kommunikation med foreningsrepræsentanterne. Samtalerne handler om både benyttelse og tilfredshed, og det understreger betydningen af disse uformelle møder og relationer som centrale for ledernes handlinger og strategier for at skabe offentlig værdi.

\section{DISKUSSION AF RESULTATER}

I dette afsnit diskuterer vi først ledernes italesættelse af anlæggets vision samt deres handlinger for at realisere visionen. Dernæst vender vi tilbage til indledningen og diskuterer, om offentlig værdiskabelse er en brugbar tilgang for ledere af idrætsanlæg i forhold til at tackle idrætsanlægs udfordringer.

\subsection{Lederes italesættelse af vision og handlinger for at realisere visionen}

Selvom visionerne i de otte anlæg ikke er formuleret med afsæt i Moore's tanker om offentlig værdi, så sigter alle visionerne på at skabe offentlig værdi. Der er midlertidigt forskel på, hvem visionerne sigter at skabe offentlig værdi for, og det er ikke alle anlæggenes visioner, som lever op til formålsformuleringerne i kommu- 
nernes facilitetspolitikker. Det fremgår af tabel 4 herunder, som viser, at fem anlæg har fokus på skabelse af offentlig værdi for lokalsamfundet, mens tre anlæg kun fokuserer på offentlig værdi for idrætsforeninger. Når det kommer til handlinger for at øge benyttelse og tilfredshed, så sker der et skifte i de anlæg, hvor fokus er på offentlig værdi for lokalsamfundet. Handlinger for at realisere visionen har overvejende udgangspunkt i idrætsforeninger, og alle ledere har operationelt fokus på at skabe offentlig værdi for idrætsforeninger. Den fokusering afspejler en prioritering af idrætsforeninger, som ikke kan aflæses direkte af facilitetspolitikkerne, men som illustreres i et interview med en forvaltningschef i en kommune: "Altså, hvis jeg skal sætte det $i$ en prioriteret form, fordi jeg har egentlig lyst til at sige alle borgere, men så er prioriteten bestemt den frivillige indsats $i$ vores foreninger (...) Men jeg mener bestemt også, at vi skal have øje for alle de andre, og det er sådan set heller ikke alle borgere, der synes, det er fedt at være medlem af en forening”. Forvaltningschefen udtrykker, som det også er tilfældet blandt lederne, at idrætsforeninger er særligt prioriterede.

Tabel 4: Lederes fokus i skabelse af offentlig værdi

\begin{tabular}{|c|c|c|}
\hline & \multicolumn{2}{|c|}{ FOKUS } \\
\hline & Lokalsamfundet & Idrætsforeninger \\
\hline Anlæggets vision & Anlæg: 1, 3, 4, 5, 6 & Anlæg: 2, 7, 8 \\
\hline $\begin{array}{l}\text { Fokus i handlinger for at } ø g e \\
\text { benyttelse }\end{array}$ & Anlæg: - & Anlæg 1, 2, 3, 4, 5, 6, 7, 8 \\
\hline $\begin{array}{l}\text { Fokus i handlinger for at øge } \\
\text { tilfredshed }\end{array}$ & Anlæg: - & Anlæg 1, 2, 3, 4, 5, 6, 7, 8 \\
\hline
\end{tabular}

Ser man på visionsarbejdet i anlæggene, vurderer vi med baggrund i vores analyser, at det kun er i anlæg 2, at der er en mere bevidst kobling mellem processen om at formulere en vision og arbejdet med at realisere den. Anlæg 2 har fokus på værdi for idrætsforeninger, og lederen har et klart billede af sin opgave, samt hvordan visionen indfris. Et billede, der stemmer overens med bestyrelsens. Der er forskellige årsager til, at visionsarbejdet i de andre anlæg er udfordret. I anlæg 1, 3, 4, 5 og 6 er det visionen at være det lokale samlingssted og skabe offentlig værdi for lokalsamfundet, men det fokus skinner ikke igennem, når lederne fortæller om bestræbelserne på at optimere benyttelse og tilfredshed. Her er fokus snævert på idrætsforeninger, og intentionen om at favne borgere uden for foreningslivet føres ikke igennem. Det er der flere (mulige) årsager til. I anlæg 1, 3 og 5 er der 
uklarheder i rollefordelingen mellem leder og bestyrelse. Nok peger begge parter på, at bestyrelsen har ansvaret, men det skinner alligevel igennem i interviews, at det er uklart, hvor grænserne går, og der er heller ikke fuld enighed om visionens indhold. Forskellige forestillinger om visionens indhold - og ikke mindst hvordan den indfris - skinner også igennem i anlæg 4, 6, 7 og 8. En kilde til uklarheder er den begrænsede brug af skriftligt materiale i visionsarbejdet. I fem af anlæggene (1, 2, 3, 7 og 8) eksisterer visionen på skrift, men det er kun i anlæg 2, at den skriftlige vision fungerer som en rettesnor for visionsarbejdet. I anlæg 1 og 3 er de skriftlige visioner etableret på grund af kommunale krav, og de er ikke særligt præsente i ledernes hukommelse. I anlæg 7 og 8 er de skriftlige visioner ikke specifikke for de to anlæg, men for alle anlæggene i kommunen, og det er derfor svært at vurdere for lederne, hvad de bliver målt på og skal leve op til. De skriftlige visioner har således begrænset indflydelse på ledernes daglige ledelsespraksis i anlæg 1, 3, 7 og 8. I anlæg 4, 5 og 6 er visioner ikke nedskrevet, og det virker uklart, hvad det præcise indhold i dem er.

De fleste ledere efterlyser klarere målsætninger at agere ud fra, end der er formuleret i facilitetspolitikkerne, men analysen viser også, at lederne har begrænset fokus på facilitetspolitikkerne og deres indhold. I et anlæg forklarer en leder, at anlæggets vision "er opstået som en del af min opdragelse, og stammer fra dengang, jeg selv kom $i$ hallen" (interview med leder). I et andet anlæg forklarer en leder, at det er "nødvendigt for en virksomhed [kommune] at have en vision og nogle mål", men samtidigt fortæller lederen, at han ikke kan huske indholdet i kommunens vision for anlægget, eller om der er kommet en ny (vores indsætning) (interview med leder). Facilitetspolitikkerne synes således at efterlade et for stort fortolkningsrum for offentlig værdiskabelse til lederne. Således fortæller lederen i anlæg 6, at det ville være nemmere, hvis der var nogle konkrete mål at arbejde ud fra, mens lederen i anlæg 5 fortæller, at det er svært at agere som leder, fordi det er uklart, hvad man bliver målt på. Det gør kerneopgaven for lederne i de fleste anlæg uklar. En del ledere (anlæg 3, 4, 5, 6 og 7) har derfor også søgt at få præciseret deres stillingsbeskrivelser. I den travle hverdag synes det således at være svært for lederne at håndtere det store fortolkningsrum, som der findes i facilitetspolitikkerne, og visionsarbejdet fortaber sig derfor oftest i daglige driftsgøremål.

\subsection{Artiklens bidrag}

Set i et ledelsesteoretisk perspektiv er der altså umiddelbart elementer af transformativ ledelse til stede, idet lederne er i stand til at formulere en vision for anlægget. I hvilket omfang visionerne fører til reel skabelse af offentlig værdi på den måde, som er ønsket i formåls- og visionsformuleringerne, synes tvivlsomt. Det skyldes to forhold. For det første har lederne svært ved at definere og tænke i offentlig værdi. Dette forhold knytter an til en central udfordring i Moore's ledelsestilgang, som 
går på, at offentlig værdi er svært at definere (Rhodes \& Wanna, 2007, 2009). Her spiller det ind, at facilitetspolitikkerne kun indeholder overordnede formuleringer om, hvilken offentlig værdi idrætsanlæggene skal skabe, og lederne er udfordret i forhold til at udfylde dette vakuum (dvs. agere som "explorers"). I anlæg 2, 7 og 8 bliver fokus snævert på idrætsforeninger og skabelse af offentlig værdi for dem. I anlæg 1, 3, 4, 5 og 6 er der et bredere fokus på lokalsamfundet, men her begrænses intentionerne om at skabe offentlig værdi af, at lederne i deres praktiske handlinger ikke fokuserer på lokalsamfundet. Dette er sammenfattet i det andet forhold, som også er relateret til Moore's teori. Kernen i Moore's ledelsestilgang er den strategiske trekant (se figur 1), som betoner vigtigheden af sammenhæng mellem vision og operationel kapacitet/handlinger. I denne artikel kommer det til udtryk som sammenhænge mellem ledernes italesættelse af vision og handlinger for at realisere visionen. I alle anlæg, bort set fra anlæg 2, finder vi tegn på, at lederne er udfordrede $\mathrm{i}$ forhold til at igangsætte handlinger, der fører dem tættere på en realisering af visionen. Der måles ikke bevidst på nogle af faktorerne, som er knyttet til værdiskabelse (tilfredshed og benyttelse), og der er stort set ikke nogen skriftligt formulerede strategier eller handlinger for, hvordan visionen skal indfris. I anlæg 1, 3, 4, 5 og 6 betyder det, at ambitionerne om at skabe offentlig værdi for lokalsamfundet negligeres, mens skabelsen af offentlig værdi for idrætsforeninger halter i anlæg 4, 7 og 8. Et første skridt mod at øge idrætsanlægs skabelse af offentlig værdi går på, som det også er formuleret af Ledelseskommissionen, at sætte borgere og lokalsamfund først. Det vil kræve et operationelt (alle anlæg) og visionært (anlæg 2, 7 og 8) skifte således, at lederne prioriterer deres fokus på lokalsamfundet. Der vil være tale om et markant skifte, som lederne formentlig ikke vil kunne skabe alene.

I vores optik er to forhold centrale at fokusere på for at understøtte lederne i dette skifte. For det første peger den nuværende lovgivning i retning af fokus på idrætsforeninger, da det offentlige tilskud gives i forlængelse af folkeoplysningsloven. Loven fører til en særlig opmærksomhed fra ledernes side på foreningernes brug af anlæg, da det på den korte bane er foreningernes brug, som sikrer økonomiske tilskud og anlægs overlevelse. Set i et historisk institutionelt perspektiv har det kontinuerlige fokus på foreningernes brug af anlæg skabt en stiafhængighed, der resulterer $i$, at foreningerne, som det også forklares af en forvaltningschef oven for, ses som de prioriterede brugere (Forsberg og Iversen, 2019). Det kommer til udtryk i de otte idrætsanlæg ved, at lederne især har fokus på handlinger, som skaber offentlig værdi for idrætsforeningerne, uanset at der i de tre kommuners facilitetspolitikker er fokus på en bredere brug, som ikke tilskriver foreninger eneret. I den optik er det væsentligt, at kommunernes tilskudsmodeller i praksis tager udgangspunkt i foreningsbrug. For det andet er det en udfordring, at lederne i anlæggene har få ansatte og dermed ofte selv er involveret i mange forskelligartede op- 
gaver, som tæller alt fra rengøring til fremtidsplanlægning. Dermed bliver lederen en blæksprutte, der skal varetage en lang række opgaver, og i det spil synes langsigtede strategiske overvejelser om offentlig værdiskabelse at fortabe sig i daglige driftsopgaver. I en sådan hverdag kommer fokus i eksekveringen af visionen let til at være på de aktuelle brugere (dvs. primært idrætsforeninger) og deres ønsker og behov. Der er i alle anlæg (bort set fra anlæg 2) behov for en klarere definition af, hvordan visionsarbejdet skal eksekveres. Lederne efterspørger klarere rammer at agere ud fra, og med tanke på, at hovedansvaret for visionsarbejdet ligger hos den øvre ledelse (jf. tabel 2), kunne det indikere et behov for, at den øvre ledelse bliver mere tydelig på og involveret $\mathrm{i}$, hvordan der sikres kobling mellem handlinger og indfrielse af vision (dvs. første og tredje hjørne i den strategiske trekant, se figur 1).

Denne artikel identificerer en række udfordringer og barrierer i forhold til at skabe offentlig værdi i idrætsanlæg. Artiklen peger på, at der er behov for, at forventningerne til de enkelte anlæg defineres tydeligere. Klarere forventninger og målsætninger fra politikere såvel som den øvre kommunale ledelse kunne støtte institutionslederne i at skabe offentlig værdi. I ingen af de otte anlæg måles der systematisk på anlæggenes præstation, og det stiller lederne i idrætsanlæggene i en svær situation. Flere af dem efterspørger klarere retningslinjer for deres arbejde, som måske kan skabes via måling og brug af indikatorer. Vi kan med baggrund i vores materiale ikke entydigt sige, om de manglende evner til at skabe offentlig værdi og følge op på den italesætte vision, er knyttet til ledernes uddannelsesbaggrund, men det er tydeligt, at klarere retningslinjer (og evt. målinger) vil kunne støtte op om ledernes indsats. Men at det ikke alene er lederuddannelse, der er årsag til udfordringerne for lederne af idrætsanlæg, viser resultaterne af en undersøgelse af offentligværdiskabelse på tværs af forskellige offentlige ledere (fra sikkerhedsområdet, sundhedsområdet, børneområdet, uddannelsesområdet og miljø- og klimaområdet) (Pedersen \& Renard, 2017). Denne undersøgelse viser udfordringer, som minder om dem, som vi har identificeret i denne undersøgelse af idrætsanlæg. Lederne på de nævnte områder finder det svært at definere offentlig værdi, da det ofte er åbent for fortolkning og ikke er dem givet fra politisk side. Men det fremgår også af denne bredere analyse, at lederne på de undersøgte velfærdsområder synes at være bedre klædt på til at håndtere kompleksiteten. De har en klar faglig identitet. De har en lederuddannelse. Og de evner at skabe innovative løsninger på de komplekse problemer de møder (Pedersen \& Renard, 2017). Dermed synes disse ledere at have bedre forudsætninger til at møde den komplekse udfordring med at sætte sig i spidsen for skabelsen af offentlig værdi. 


\section{KONKLUSION}

Artiklen har vist, at selv om lederne i de fleste tilfælde er i stand til at italesætte en vision for, hvordan idrætsanlæggene kan bidrage til skabelsen af offentlig værdi, arbejdes der ikke særlig bevidst med at skabe offentlig værdi i idrætsanlæg. En særlig begrænsning for at have et tilstrækkeligt fokus på at skabe offentlig værdi i de otte anlæg er, at lederne operationelt har fokus på de eksisterende brugere i form af idrætsforeninger. Lederne skaber således primært offentlig værdi i forhold til idrætsforeningerne, og ledernes fokus på idrætsforeninger synes i nogen grad at hindre, at der tages ledelsesmæssige initiativer, der i højere grad peger i retning af at indfri den vision, som formuleres i mange anlæg og kommuner: At være det lokale samlingssted og derigennem skabe offentlig værdi for hele lokalsamfundet. Lederne iværksætter få handlinger, der rækker ud til andre brugergrupper end idrætsforeningerne.

Man kan diskutere denne præmis: At skabelse af offentlig værdi er noget, der hensigtsmæssigt rækker ud over idrætsforeninger. Denne præmis er knyttet til idrætsanlægs legitimitet (dvs. det andet hjørne i Moore’s strategiske trekant), som vi ikke har fokuseret indgående på i analysen. Den kontinuerlige økonomiske støtte fra kommuner til idrætsanlæg over tid (fra begyndelsen af 1900-tallet før kommuner var forpligtet hertil lovmæssigt (Forsberg \& Iversen, 2019)) kan være et udtryk for, at idrætsanlæg ved at være ramme om idrætsforeninger har skabt offentlig værdi. Idrætsanlæg har således været opfattet som legitime modtagere af offentlige midler, fordi de har understøttet foreningers aktiviteter og trivsel. I dag synes der dog at være stigende opmærksomhed på, at anlæggene skal kunne mere end at være en foreningsramme, og at det i stigende grad fra kommunerne forventes, at idrætsanlægs skabelse af offentlig værdi skal komme andre end alene foreningerne til gavn. Det finder vi i kommunernes facilitetspolitikker og i de fleste visioner i anlæggene. Det fokus skal ses i lyset af, at anlæggene ikke benyttes så optimalt som de kunne (Høyer-Kruse et al., 2017). Der synes dermed at være en opfattelse af, at anlæggene skal være mere end en foreningsramme, og det gør skabelse af offentlig værdi for lokalsamfundet relevant.

Artiklen viser desuden, at lederne i syv af de otte anlæg har udfordringer i forhold til at indfri anlæggets vision. Såvel lederne som deres øvre ledelse har en forestilling om en vision for anlægget, men umiddelbart tyder det ikke på, at ledernes daglige handlinger understøtter indfrielsen af visionen. Brugernes tilfredshed og anlæggets benyttelse er centrale delmål, men der findes ikke nogle overordnede mål for tilfredshed og benyttelse, og der mangler en systematisk tilgang til at optimere dem. De fine hensigtserklæringer drukner i hverdagen.

Set i forhold til ledere af andre velfærdsinstitutioner har ledere af idrætsanlæg i mindre grad en ledelsesmæssig uddannelse. Det synes at være et oplagt sted at starte, hvis man ønsker at klæde lederne af idrætsanlæg bedre på til at løse opga- 
ven med at skabe offentlig værdi. Men det er en betydelig udfordring at løfte at tilegne sig sådanne komplekse egenskaber. I nogle tilfælde synes det derfor at være sandsynligt, at det mest realistiske scenarie er, at lederen må udskiftes eller tildeles andre arbejdsopgaver.

Vi har kun lavet et nedslag på et bestemt tidspunkt. Derfor kan vi ikke sige noget om, hvad der over tid skal til for at ledere af idrætsanlæg i højere grad arbejder i retning af at øge skabelsen af offentlige værdi. For at komme tættere på en nærmere forståelse af, hvilken betydning eksempelvis en ny leder med en anden og mere udpræget ledelsesbaggrund vil have, vil det være oplagt, hvis fremtidig forskning i højere grad fokuserer på, hvordan sådanne ændringer af ledelsen påvirker fokus i idrætsanlæg og handlinger i forhold til at skabe offentlig værdi. Med afsæt i nærværende undersøgelse vil det $\mathrm{i}$ et sådant studie være yderst relevant at forsøge at følge, i hvilken grad ændringer i typen og sammensætningen af ledelsen har betydning for at få andre end foreninger ind i idrætsanlægget.

\section{REFERENCER}

Alford, J., \& Flynn, J. O. (2009). Making Sense of Public Value : Concepts, Critiques and Emergent Meanings. International Journal of Public Administration, 32(3-4), 171-191. https://doi.org/10.1080/01900690902732731

Andersen, L. B., Andersen, S. C., \& Pallesen, T. (2016). Forskning i ledelseseffekter på borgernes udbytte af de offentlige ydelser: styrker, svagheder og fremtidige perspektiver. Politica, 48(2), 113-134.

Andersen, L. B., Jakobsen, M. L., Serritzlew, S., \& Pallesen, T. (2010). Økonomiske incitamenter i den offentlige sektor. Aarhus: ViaSystime.

Bozeman, B. (1984). Dimensions of "publicness": An approach to public organization theory. In B. Bozeman \& J. Straussman (Eds.), New directions in public administration. Monterey, CA: Brooks/Cole.

Bro, L. L. (2016). Små , store eller måske rettere mellemstore organisationer ? En undersøgelse af sammenhængen mellem ledelsesspænd, ledelsesidentitet og brugen af transformationsledelse i danske daginstitutioner. Politica, 48(2), 158-178.

Danmarks Statistik. (2017). Idrættens økonomi. Data hentet fra Danmarks Statistiks Statistikbank, d. 25.02, 2019.

Flyvbjerg, B. (2006). Five Misunderstandings About Case-Study Research. Qualitative Inquiry, 12(2), 219-245.

Forsberg, P., \& Iversen, E. B. (2019). The Influence of Voluntary Sports Clubs on the Management of Community Sports Facilities in Denmark. International Journal of Sport Policy and Politics. Retrieved from https://doi.org/10.1080/19406940.2019.1595699

Forsberg, P., Iversen, E. B., \& Høyer-Kruse, J. (2017). Organisering, styring og ledelse af idrætsfaciliteter i Danmark. København: Idrættens Analyseinstitut. https://idan.dk/ 
vidensbank/udgivelser/organisering-styring-og-ledelse-af-idraetsanlaeg-i-danmark/ eeo2b5eo-4586-4322-9bee-a8180093fbc2

Gerring, J. (2004). What Is a Case Study and What Is It Good for? American Political Science Review, 98(2), 341-354.

Greve, C. (2009). Strategisk offentlig ledelse set ud fra Moores teori om offentlig værdiskabelse. Tidsskriftet Politik, 12(2), 32-40.

Høyer-Kruse, J., Iversen, E. B., \& Forsberg, P. (2017). Idrætsanlægs benyttelse og brugernes tilfredshed. Odense: Center for forskning i Idræt, Sundhed og Civilsamfund, Syddansk Universitet. https://idan.dk/vidensbank/udgivelser/idraetsanlaegs-benyttelse-og-brugernes-tilfredshed/bac7cc5a-14ob-4ea6-87e6-a81fooa1ff52

Ibsen, B. (2011). Kommunalreformens betydning for kommunernes idrætspolitik. Økonomi \& Politik, 2, 42-51.

Ibsen, B., Nichols, G., \& Østerlund, K. (2016). Sports Clubs Policies in Europe. Odense: Center for forskning i Idræt, Sundhed og Civilsamfund, Institut for Idræt og Biomekanik, Syddansk Universitet. Hentet fra https://idan.dk/vidensbank/udgivelser/ sports-club-policies-in-europe-a-comparison-of-the-public-policy-context-and-historical-origins-of-sports-clubs-across-ten-european-countries/af8c1b86-52a3-4efo-b6foa7d6ooe6611d

Iversen, E. B. (2015). Public Management of Private Non-Profit Sports Halls. Odense: Center for forskning i Idræt, Sundhed og Civilsamfund, Institut for Idræt og Biomekanik, Syddansk Universitet. Hentet fra https://idan.dk/vidensbank/udgivelser/public-management-of-private-nonprofit-sports-halls/368ef129-bbd2-4333-9a7e-a510ooc32145

Iversen, E. B. (2017). Does size matter when public management tools meet (the voluntary) reality in sports facilities? World Leisure Journal, 59(1), 54-69. https://doi.org/10.1080/16078055.2016.1277612

Iversen, E. B. (2018). Public Management of Sports Facilities in times of austerity. International Journal of Sport Policy and Politics, 10(1), 79-94. https://www.tandfonline. com/doi/abs/10.1080/19406940.2018.1426621?journalCode=risp20

Iversen, E. B., \& Forsberg, P. (2014). Mål eller kaos? - Muligheder og begrænsninger i at indføre performance management i danske idrætsfaciliteter. Forum for Idræt, 30 (1), 36. https://tidsskrift.dk/forumforidraet/article/view/31969/29402

Klausen, K. K. (2006). Institutionsledelse - ledere, mellemledere og sjakbajser i det offentlige. L\&R Business.

Klausen, K. K., Michelsen, J., \& Nielsen, D. M. (2011). Den decentrale leder. København.

Kulturministeriet. (2014a). Udredning af idrættens økonomi og struktur. Analyse. København: Kulturministeriet.

Ledelseskommissionen. (2018). Sæt borgerne først. København: Ledelseskommsissionen. https://ledelseskom.dk/files/media/documents/hovedpublikationer/saet_borgerne_ foerst_-_ledelseskommissionens_rapport.pdf 
Michelsen la Cour, A. (2013). Casestudiet. In L. F. Thing \& L. Ottesen (Eds.), Metoder $i$ idrætsforskning (1. udgave, s. 190-206). København: Munksgaard.

Miles, M. B., \& Hubermann, M. (1994). Qualitative Data Analysis (Second). Thousand Oaks: Sage Publications.

Moore, M. H. (1995). Creating public value, strategic management in government. Cambridge: Harvard University Press.

Moore, M. H. (2000). Managing for Value : Organizational Strategy in For-Profit, Nonprofit , and Governmental Organizations. Nonprofit and Voluntary Sector Quarterly, 29(1), 75-78.

Moore, M. H. (2013). Recognizing Public Value. Cambridge: Harvard University Press.

Pedersen, A. R., \& Renard, C. C. (2017). Introduktion. In C. Renard \& A. R. Pedersen (Eds.), Når ledere skaber offentlig værdi . Seks fortællinger fra samfundets maskinrum. Nyt fra samfundsvidenskaberne.

Pors, N. O. (2005). Mellem identitet og legitimitet. Forandringer, kultur og ledelse i danske folkebiblioteker. København.

Pors, N. O. (2010). Citizen services and public libraries : an analysis of a new service in Danish public libraries. New Libary World, 111(7/8), 253-272. DOI: https://doi. org/10.1108/03074801011059902

Regeringen. (2017). Kommissorium for ledelseskommissionen. København: Regeringen. https://ledelseskom.dk/sites/ledelseskom.dk/files/media/documents/kommissorium_ledelseskommissionen.pdf

Rhodes, R. A. W., \& Wanna, J. (2007). The Limits to Public Value, or Rescuing Responsible Government from the Platonic Guardians. The Australian Journal of Public Administration, 66(4), 406-421. https://doi.org/10.1111/j.1467-8500.2007.00553.x

Rhodes, R. A. W., \& Wanna, J. (2008). Stairways to Heaven: A Reply to Alford. The Australian Journal of Public Administration, 67(3), 367-370. https://doi.org/10.1111/j.14678500.2008.00594.x

Rhodes, R. A. W., \& Wanna, J. (2009). Bringing the Politics Back in: Public Value in Westminister Parliamentary Government. Public Administration, 87(2), 161-183. https:// doi.org/10.1111/j.1467-9299.2009.01763.x

Stake, R. (1995). The art of case study research. Thousand Oaks: Sage Publications.

Yin, R. K. (2014). Case Study Research. Design and Method (5th ed.). London: SAGE. 


\section{Dansk abstrakt}

Denne artikel undersøger otte ledere af idrætsanlægs skabelse af offentlig værdi med baggrund i Ledelseskommissionens anbefaling om, at offentlige velfærdsinstitutioner skal sætte borgerne først og skabe værdi for hele lokalsamfundet. Artiklen anvender Moore's (1995) teori om offentlig værdiskabelse til at undersøge, hvordan lederne i anlæggene italesætter anlæggets vision om værdiskabelse, samt hvilke handlinger lederne tager for at nærme sig visionen. Artiklen viser, at lederne har intentioner om at skabe værdi for idrætsforeninger og borgere bredt set, men at lederne operationelt fokuserer på idrætsforeningerne. Intentionerne om også at have fokus på borgere bredt set, fortaber sig i de daglige driftsopgaver.

\section{English abstract}

This article examines how eight Danish sports facilities' managers create public value. The Management Commission recommends public institutions to put citizens first and create value for all the local community members. The article uses Moore's (1995) theory on creating public value to examine how managers in sports facilities articulate their vision on public value creation and the efforts managers take to fulfill their vision. The article shows that managers' intend to create public value for the sports clubs and local community members. However, managers' intentions get lost in the daily operations and managers primarily focus on value for sports clubs.

\section{Forfatteroplysninger}

Peter Forsberg er ph.d.-stipendiat ved Idrættens Analyseinstitut og Center for forskning i Idræt, Sundhed og Civilsamfund ved Institut for Idræt og Biomekanik på Syddansk Universitet. Peter Forsberg har stor erfaring i undersøgelser af kommuner, idrætsanlæg og idrætsforeninger og skriver ph.d. om ledelse af idrætsanlæg.

Evald Bundgård Iversen er ph.d. og lektor på Center for forskning i Idræt, Sundhed og Civilsamfund ved Institut for Idræt og Biomekanik på Syddansk Universitet, hvor hans primære forskningsområder i øjeblikket er organisering, styring og ledelse af idrætsfaciliteter samt samspillet mellem kommuner og civilsamfund. 